\title{
Ostracods (Crustacea) from thermal waters, southern Altiplano, Argentina
}

\author{
Cecilia Laprida ${ }^{1}$, Analia Díaz ${ }^{2}$ and Norma Ratto ${ }^{3}$ \\ ${ }^{1}$ Departamento de Ciencias Geológicas, Facultad de Ciencias Exactas y Naturales, Universidad de Buenos Aires, \\ Argentina, Ciudad Universitaria, Pab. 2, $1^{\circ}$ piso. 1428 Ciudad de Buenos Aires, Argentina \\ email: chechu@gl.fcen.uba.ar \\ ${ }^{2}$ Cátedra Zoología Invertebrados I, Facultad de Ciencias Naturales y Museo, \\ Universidad Nacional de La Plata, La Plata, Argentina \\ email: ostracodiaz@fcnym.unlp.edu.ar \\ 3: Museo Etnográfico, Facultad de Filosofía y Letras, Universidad de Buenos Aires. Buenos Aires, Argentina \\ email: nratto@ciudad.com
}

\begin{abstract}
The ostracod fauna from la Terma hot spring (265ㄴ $31^{\prime \prime} \mathrm{S}-68^{\circ} 08^{\prime} 45.7^{\prime \prime} \mathrm{W}, 4026 \mathrm{~m}$ above sea level), Southern Altiplano, Argentina, is described and the pool itself characterized. The occurrence of ostracods in this type of environments is registered for the first time in Argentina. Six species were found, two of which is new to the fauna of Argentina: Penthesilenula incae (Delachaux) and Hemicypris panningi (Brehm). Two species were found for the first time in the Altiplano: H. panningi (Brehm) and Cypridopsis fuhrmanni (Méhes). Some comments concerning how and when these species could spread to populate the Dry Altiplano are discussed briefly taking into account paleoclimatic data. This paper provides the first record of ostracods from the Southern Altiplano, Argentina.
\end{abstract}

\section{INTRODUCTION}

The southern Altiplano (NW Argentina, South America) has several archaeological sites that certify the occupation of highland settings by hunter-gatherer groups since $8000 \mathrm{yr}$ before present (Ratto 2000). It is generally accepted that these hunter-gatherer populations were strongly influenced by environmental and climatic factors. The knowledge of holocene climate fluctuations will help to determine the impact of climate change in the evolution of these ancient societies. This requires the analysis of high-resolution natural archives containing centennial- to- millennial-scale records.

Several sources of holocene continental records were identified in Catamarca, Southern Altiplano. Paleolakes and other fossil environments were sampled in order to obtain natural archives of paleoenvironmental evolution, including ostracods (Valero-Garcés et al. 2000, 2003). Ostracods are excellent paleoenvironmental indicators and they have proved to be valuable in paleolimnology. They are widely distributed in all aquatic habitats and very sensitive to water conditions, specially conductivity, $\mathrm{pH}$, and chemical composition. Valves can easily fossilize and represent one of the principal sources of biogenic carbonate in continental environments.

The application of ostracod analysis to quaternary paleoclimatic reconstructions requires a database concerning the modern ecology and the distribution patterns of local species in order to extrapolate these data to the fossil record. Because present knowledge of ostracods from the Southern Altiplano is limited, samples from different modern aquatic habitats in Catamarca were taken to provide better insight into the relationship between distribution of species and environmental parameters.
Our main objective here is to describe the ostracod fauna inhabiting in an isolated hot spring in the Southern Altiplano, at ca. $4000 \mathrm{~m}$ above sea level. Firstly, we describe the morphology and the taxonomic position of species. Some physicochemical properties are given in order to allow the application of these data to paleolimnology and paleoclimatic reconstructions. Finally, some comments concerning how and when these species could spread to populate these isolated settings are discussed briefly taking into account paleoclimatic data.

\section{PREVIOUS WORKS}

The knowledge of recent freshwater ostracods from South America is still incomplete (Mourguiart and Montenegro 2002). Martens and Behen (1994) and Martens et al. (1998) have listed about 300 present-day species but some regions have been neglected and there are a lot of unexplored areas, so we consider that the number of species must be higher. Ostracods from the Peruvian Altiplano have been early described by Delachaux (1928), but much of our knowledge of quaternary and recent ostracods comes from the Titicaca Lake in Bolivia (Mourguiart 1992, 2000, Mourguiart et al. 1992, 1997, 1998 and Mourguiart and Corrège 1998). Recently Schwalb et al. (1999) analyzed fossil holocene ostracods from sediment cores from Chilean Altiplano lakes. More to the south in the Andes but outside the Altiplano, some recent species have been reported from Andean lakes of Mendoza (Mèhes 1914) and from Patagonia (Daday 1902, Whatley and Cusminsky 1995, 1999, 2000; Cusminsky and Whatley 1996, Schwalb et al. 2002). This paper provides the first record of ostracods from the Southern Altiplano, Argentina.

\section{MATERIALS AND METHODOLOGY}

Samples were collected in northwest Tinogasta County, Catamarca province, Argentina (text-fig. 1). Altitude varies be- 


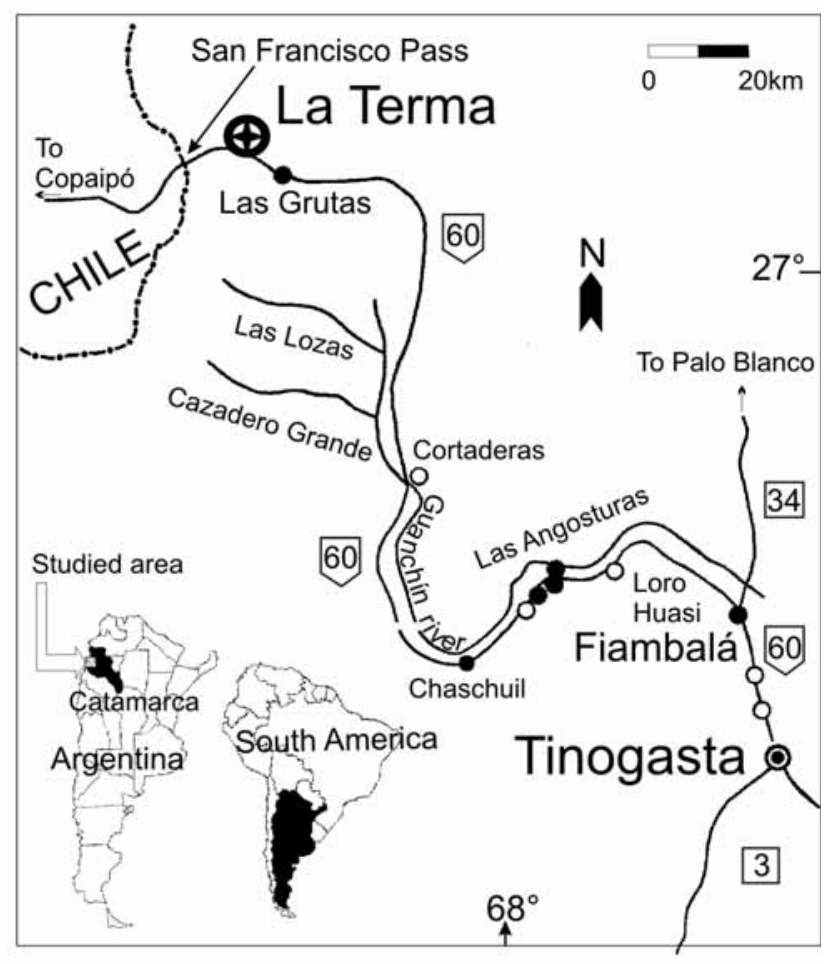

TEXT-FIGURE 1

Map of Tinogasta, Catamarca, Northwestern Argentina. The map shows the approximate location of the sampled site. La Terma hot spring is $21 \mathrm{~km}$ to the San Francisco International Pass to Chile. The area belongs to the Southern Altiplano for its phytogeography but also for its geological and structural features.

tween $3500 \mathrm{~m}$ and $4700 \mathrm{~m}$ above sea level. The region is flanked by mountain chains: the Cordillera de San Buenaventura to the north, the Sierra Las Planchadas to the east, and the Cordillera de los Andes to the west. The area belongs to the Puneña Province of the Andean Dominion (Cabrera 1976, Cabrera and Williink 1980). The region is considered belonging to the Southern Altiplano not only for its phytogeography but also for its geological and structural features (cf. Argerich 1976, Costello and Aguirre de Costello 1999).

The area is characterized by a very dry, cold climate and summer (December-March) rains. Precipitations are less than $100 \mathrm{~mm} /$ year and the evaporation is $c a .-570 \mathrm{~mm} /$ year, which denotes high evaporation rates (Buitrago and Larrán 1994; Morlans written communication, 1985). Snow is the dominant moisture source in winter. There is high daily thermal amplitude and well marked seasonality. Temperatures in summer vary between $c a .20^{\circ} \mathrm{C}$ to $c a .-10^{\circ} \mathrm{C}$ during nights while in winter temperatures can reach easily $-20^{\circ} \mathrm{C}$. Springs and a few perennial creeks are focal points for any life present.

In this study, thermal water designates an aquatic habitat in which temperature is higher than the mean annual temperature of the region. The sampled site $\left(26^{\circ} 55^{\prime} 31.0^{\prime \prime} \mathrm{S}-68^{\circ} 08^{\prime} 45.7^{\prime \prime} \mathrm{W}\right.$, $4026 \mathrm{~m}$ asl) is situated near Las Grutas, at $21 \mathrm{~km}$ to the international San Francisco Pass to Chile. It is a little stream of 8-10m wide and $40-50 \mathrm{~cm}$ deep originated in a well of thermal water. Temperature in the well was $38^{\circ} \mathrm{C}$. Sediments at the bottom are medium and coarse sands and fine gravels. The current speed is $c a$. $0.5 \mathrm{~m} / \mathrm{sec}$. The surface is covered by floating and rooting vegetation.

Samples, sampling dates, microhabitat description, temperature, $\mathrm{pH}$ and conductivity are consigned in Table 1. Sediment samples were hand taken with a sieve $(10 \mathrm{~cm}$ diameter, mesh of $100 \mu \mathrm{m})$ from the first $2-3 \mathrm{~cm}$ of bottom sediments. Samples of macrophytes were taken with a net (diameter $30 \mathrm{~cm}, 50 \mathrm{~cm}$ long and mesh of $55 \mu \mathrm{m}$ ). Water temperature, $\mathrm{pH}$ and conductivity were measured with a portable pHmeter Hanna model HI 8424. Water analysis was made by the Instituto Nacional de Geología Isotópica (INGEIS), Argentina. In this study, only living individuals (specimens containing soft parts even when they were not well preserved) were considered.

Samples were washed with running water and dried in a stove at $40^{\circ} \mathrm{C}$. Dried samples were examined and picked. Carapaces and valves were described as only they are usually preserved in fossil sediments. Soft parts were considered only in order to confirm systematic position in the Darwinulidea. The dry soft parts were placed in a one-cavity glass-slide containing a $2 \%$ solution of trisodium phosphate during 24-36 hours for softening (Moguilevsky written communication 1976). The material examined in this study is listed in Table 2. Analyzed material is deposited at the Departamento de Ciencias Geológicas, Universidad de Buenos Aires, Argentina. The following abbreviations are used in text and plates: $\mathbf{C p}$, carapace; $\mathbf{L V}$, left valve; RV, right valve; Cms, central muscle scar(s); Rcp, Radial pore canals; asl, above sea level; A1, antennula; A2, antenna.

\section{SYSTEMATICS}

Class OSTRACODA Latreille 1802

Subclass PODOCOPA G.W. Müller 1894

Order PODOCOPIDA Sars 1866

Superfamily DARWINULOIDEA Brady and Norman 1889

Family DARWINULIDAE Brady and Norman 1889

Genus Darwinula (Brady and Robertson 1870)

Darwinula stevensoni (Brady and Robertson 1870)

Plate 1, figures 1-6

Polycheles stevensoni BRADY and ROBERTSON 1870, p. 25, pl. 7, fig. 17, pl. 10, fig. 13.

Darwinula stevensoni (Brady and Robertson) ROSSETTI and MARTENS 1996, p. 77 and 82, figs. 2-11. - ROSSETTI and MARTENS 1998, p. 59-60, figs. 1a-f, 24d, 27a-d. - ROSSETTI, HORNE and MARTENS 1998, p. 17-22, pl. 25, 18 and 25, 20.

Material $: \overline{\overline{k T}}$ following material is deposited at the Laboratorio de Micropaleontología, Facultad de Ciencias Exactas y Naturales, Universidad de Buenos Aires; repository numbers are given in brackets: a) LV preserved on a cavity slide (FCEN-LM 2920); b) LV preserved on a cavity slide (FCEN-LM 2921); c) RV preserved on a cavity slide (FCEN-LM 2922); d) Cp preserved on a cavity slide (FCEN-LM 2923); e) LV preserved on a cavity slide (FCEN-LM 2924); RV preserved on a cavity slide (FCEN-LM 2925).

Measurements: carapace length 673-624 $\mu \mathrm{m}(\mathrm{n}=5)$; height

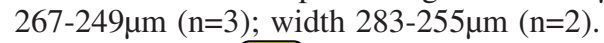

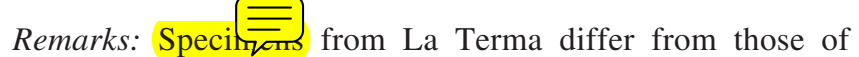
Darwinula stevensoni illustrated by Rossetti and Martens 
TABLE 1

Sampling dates, location, description of microhabitats, $\mathrm{pH}$, temperature and conductivity of samples from La Terma hot spring, Southern Altiplano.

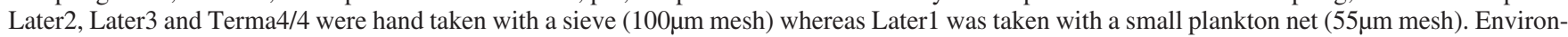
mental data were measured in situ with a portable pHmeter.

\begin{tabular}{|c|c|c|c|c|c|c|}
\hline Sample & Date & Location & Microhabitat description & $\mathrm{T}^{\mathrm{o}}$ & $\mathrm{pH}$ & Conductivity \\
\hline Later 1 & \multirow{3}{*}{$\begin{array}{l}\text { January 10th, } \\
\quad 2004\end{array}$} & \multirow{3}{*}{$\begin{array}{l}\mathrm{S} 26^{\circ} 55^{\prime} 31^{\prime \prime} \\
\text { W } 68^{\circ} 08^{\prime} 45,7^{\prime \prime}\end{array}$} & $\begin{array}{l}\text { Rooted and floating macrophythes } \\
8 \mathrm{~m} \text { downstream of a little dam }\end{array}$ & \multirow{3}{*}{$28^{\circ} \mathrm{C}$} & \multirow{3}{*}{8.3} & \multirow{3}{*}{$204 \mu \mathrm{S} / \mathrm{cm}$} \\
\hline Later2 & & & $\begin{array}{l}\text { Bottom sediments beneath Later1 } \\
\text { macrophythes, } 40 \mathrm{~cm} \text { depth. Grain } \\
\text { size: coarse sand and fine gravel }\end{array}$ & & & \\
\hline Later 3 & & & $\begin{array}{l}\text { Bottom sediments in active } \\
\text { channel, } 50 \mathrm{~cm} \text { depth. Grain size: } \\
\text { coarse sand and fine gravel }\end{array}$ & & & \\
\hline Terma $4 / 4$ & $\begin{array}{l}\text { April 12th, } \\
2004\end{array}$ & $\begin{array}{l}\mathrm{S} 26^{\circ} 55^{\prime} 31^{\prime \prime} \\
\text { W } 68^{\circ} 08^{\prime} 45,9^{\prime \prime}\end{array}$ & $\begin{array}{l}\text { Bottom sediments } 5 \mathrm{~m} \text { upstream of } \\
\text { a little dam, } 20 \mathrm{~cm} \text { depth. Grain } \\
\text { size: coarse and medium sand and } \\
\text { fine gravel with organic matter }\end{array}$ & $30^{\circ} \mathrm{C}$ & 8.1 & N/D \\
\hline
\end{tabular}

(1998) in having the posterior margin broader and symmetrically rounded. Additionally, Rossetti and Martens (1998), Rossetti et al. (1998) and Martens and Rossetti (2002), consider that Darwinula stevensoni is rather large (ca. 0.8-0.7 mm), whereas our specimens are smaller (ca. $0.65 \mathrm{~mm}$ ), but Rossetti and Martens (1996) analyzed morphological variability of $D$. stevensoni and consider that size can vary significantly between populations. They also observed small differences in the curvature of the postero-ventral corner. To confirm systematic position, soft parts were analyzed in conjunction with hard parts, and they fit well in the diagnosis of $D$. stevensoni after Rossetti and Martens (1998) and Rossetti et al. (1998): RV without external keel; LV without internal teeth; RV overlapping LV; last segment of Md-palp with four claws; A1 with second segment of endopodite with two large dor $\equiv$ of Md-palp with seta $\overline{\overline{\bar{\sigma}}}$ g, seta $\overline{\overline{\text { orrort}}}$; last segment with $\underline{\underline{a}}, \overline{\overline{\sqrt{ }}}$ and "poil stevensoni" setae.

Distribution: Darwinula stevensoni is ubiquitous and cosmopolitan. In La Terma it was registered living in association with macrophytes (Later 1) and in clean coarse-grained sands (Later 2).

\section{Genus Penthesilenula Rossetti and Martens 1998}

Penthesilenula incae (Delachaux 1928)

Plate 1, figures 7-10

Darwinula incae DELACHAUX 1928, p. $\bar{\equiv}$, pl. 5, figs. 28-39. ROSSETTI, MARTENS and MOURGUIART 1996, p. 35-40, pl. 23 , 36 and $23,38$.

Penthesilenula incae (Delachaux 1928). - ROSSETTI and MARTENS 1998 , p. 79 and 81 , figs. $13 \mathrm{a}-\mathrm{d}$ and $28 \mathrm{~g}-\mathrm{j}$.

Material: the following material is deposited at the Laboratorio de Micropaleontología, Facultad de Ciencias Exactas y Naturales, Universidad de Buenos Aires; repository numbers are given in brackets: a) RV preserved on a cavity slide (FCEN-LM 2926); b) LV preserved on a cavity slide (FCEN-LM 2927); c) RV preserved on a single cavity slide (FCEN-LM 2928); d) LV preserved dry on a cavity slide (FCEN-LM 2929).

Measurements: carapace length $695-648 \mu \mathrm{m}(\mathrm{n}=8)$; height

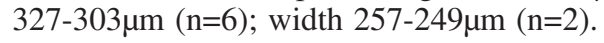

Remarks: $\overline{\overline{\overline{2}}}$ specimens are smaller than the holotype described by Delachaux (1928) from Perú and smaller than specimens described by Rossetti et al. (1996) and Rossetti and Martens (1998) from Bolivia. Additionally Cms consists in 11 small spots instead of 13-14 spots as described in Rossetti et al. (1996). Specimens from La Terma are attributed to $P$. incae because of the great similarity with the description made by Rossetti et al. (1996) and Rossetti and Martens (1998) in several diagnostic details of the appendages and valves: LV with internal tooth along the caudal margin, LV overlapping RV on all sides, first segment of A1 with two dorsal setae; second segment with three ventral setae, two short and one longer, and one short dorso-apical seta; third segment with one ventral and one dorsal seta; four segment with one ventral seta and two dorsal setae; A2 exopodite with two long setae and one short lateral spine. Specimens from La Terma are very similar to Penthesilenula setosa (Daday, 1902) described from Patagonia, but the former has an inadequate original description and probably it have to be considered as senior synonym of $P$. incae (Rossetti et al. 1996). Penthesilenula brasiliensis (Pinto and Kotzian 1961) is smaller and shorter (normal length range between 0.47-0.55 $\mathrm{mm}$ ), and it is characterized by small antero-ventral and large postero-ventral internal tooth in $\mathrm{LV}$, and Cms consisting of $c a$. 9 relatively large scars. Penthesilenula aotearoa (Rossetti and Martens $1998)$ is smaller $(0.58-0.61 \mathrm{~mm})$ and it has posterior and antero-ventral internal teeth in LV.

Distribution: Im $\overline{\overline{\overline{\bar{L}}}}$ Terma, Southern Altiplano, Penthesilenula incae was found in still water, inhabiting humic coarse-grained sands, $20 \mathrm{~cm}$ depth (Terma 4/4). It was originally described from Perú (Delachaux 1928, Mourguiart et al. 1997, 1998) and thereafter found in Bolivian lakes (Rossetti et al. 1996).

Infraorder CYPRIDOCOPINA Jones 1901

Superfamily CYPRIDOIDEA Baird 1845

Family CANDONIDAE Kaufmann 1900

Subfamily CANDONINAE Kaufmann 1900

Genus Candona Baird 1845

Candona sp.

Plate 1, figure 11

Material: the following material is deposited at the Laboratorio de Micropaleontología, Facultad de Ciencias Exactas y Naturales, Universidad de Buenos Aires; repository numbers 
are given in brackets: a) RV from Later1 preserved on a cavity slide (FCEN-LM 2930).

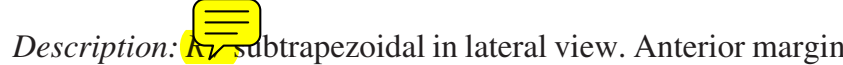
obliquely rounded, asymmetric; posterior margin rounded. Dorsal margin short and straight, with a soft inclination to the anterior margin; cardinal anterior angle visible; posterior angle not visible. Ventral margin sub-parallel to the dorsal margin, weakly sinuous with a concavity in the mid-length. Surface of valves smooth, with just few simple normal pores. Few long setae more abundant at the anterior margin. Greatest height coincident with the posterior third of the valve, greatest length just in the mid-height. Hinge adont. Cms consisting of a dorsal compact group of scars and six shorter scars that formed a rosette. Calcified inner lamella widest in the anterior margin with a well developed vestibule.

Measurements: RV length $486 \mu \mathrm{m}$; height $262 \mu \mathrm{m}$.

Remarks: Candona sp. has certain similarities with Candona pedropalensis Mèhes, 1914 but the former is more elongated and the dorsal margin is arched while in Candona sp. the dorsal margin is shorter and straight. Candona sp. has also some similarities with Candona incarum (Moniez 1889) described from the Titicaca Lake, Bolivia, but its dorsal margin is shorter and straighter.

Local distribution: a single valve of Candona sp. with soft parts not well preserved was found among macrophytes (Later1).

Family CYPRIDIDAE Baird 1845

Subfamily CYPRINOTINAE Bronstein 1947

Genus Hemicypris Sars 1903

Hemicypris panningi (Brehm 1934)

Plate 2, figures 1-7

Heterocypris panningi BREHM 1934, p. 83-84, figs. 13-14. HARTMANN 1962, p. 182. - PURPER and WÜRDIG-MACIEL 1974 , p. 77

Material: the following material is deposited at the Laboratorio de Micropaleontología, Facultad de Ciencias Exactas y Naturales, Universidad de Buenos Aires; repository numbers are given in brackets: a) $\mathrm{Cp}$ female preserved on a cavity slide (FCEN-LM 2931); b) Cp female preserved on a cavity slide (FCEN-LM 2932); c) Cp female preserved on a cavity slide (FCEN-LM 2933); d) LV female preserved on a cavity slide (FCEN-LM 2934); e) Cp male preserved on a cavity slide (FCEN-LM 2935); f) RV female preserved on a cavity slide (FCEN-LM 2936); g) LV male preserved on a cavity slide (FCEN-LM 2937).

Description: $\mathrm{Cp}$ female subtriangular, reniform in lateral view with subumbonate dorsal margin passing into anterior and posterior margins without cardinal angles. Anterior margin broadly rounded, posterior not evenly rounded. Ventral margin sinuate in the central region. Greatest height situated slightly in the front of the middle; greatest large in the $1 / 3$ of the height. RV larger and higher than LV overlapping it in the antero-dorsal margin. In dorsal view, Cp sub-elliptical, compressed. Surface of valves pitted with abundant setae. Central and dorsal muscle scars evident in external view as smooth areas. Adont hinge, $\mathrm{LV}$ with large groove, RV with corresponding smooth ridge. Cms consisting of a group of six large elongated spots typical of the genus. Calcified inner lamella widest in the anterior margin, with relatively narrow vestibule. Rcp shorts, numerous and closely spaced. Inner margin of LV with minute tubercles.

Sexual dimorphism present, males bigger and more elongated than females.

Measurements: carapace length $9675-647 \mu \mathrm{m} \quad(\mathrm{n}=5)$, $? 592-534 \mu \mathrm{m}(\mathrm{n}=3)$; height $? 420-398 \mu \mathrm{m}(\mathrm{n}=5), ? 371-347 \mu \mathrm{m}$ $(\mathrm{n}=2)$; width $? 292 \mu \mathrm{m}(\mathrm{n}=1)$.

Remarks: Ths species has been ascribed to Heterocypris (Brehm 1934, Purper and Würdig-Maciel 1974, Martens and Behen 1994) but actually it belongs to Hemicypris because RV is larger than LV and the free margin of LV has minute tubercles. It can be easily distinguished because is smaller than the majority of South American species of Hemicypris and because both valves are subtriangular in lateral view. It is rather similar to Heterocypris wolffhugeli (Mèhes, 1914), but in the former the dorsal margin of the LV is evenly arched, whereas in Hemicypris panningi is pointed in the front of the mid-length.

Distribution: Hemicypris panningi is the most abundant species in La Terma. It was found living attached to rooted macrophytes (Later1) as well as in clean and humic coarse-grained sediments (Later2 and Terma 4/4). It was previously registered from Chile and Perú (Brehm 1934, Klie 1941, Hartmann 1962).

Subfamily HERPETOCYPRIDINAE Kaufmann 1900

Genus Herpetocypris Brady and Norman 1889

\section{Herpetocypris sp.}

Plate 2, figure 8

Material: the following material is deposited at the Laboratorio de Micropaleontología, Facultad de Ciencias Exactas y Naturales, Universidad de Buenos Aires; repository numbers are given in brackets: a) one immature LV preserved on a cavity slide (FCEN-LM 2938).

\section{Measurements: LV length $876 \mu \mathrm{m}$, height $400 \mu \mathrm{m}(\mathrm{n}=1)$}

Remarks: Herpetocypris sp. is quite similar in outline to Herpetocypris reptans (Baird 1835), a cosmopolitan, widely distributed species inhabiting in ponds, small lakes and slowly flowing waters. In accordance to diagnosis (González Mozo et al. 1996) the length of Herpetocypris carapaces varies between $1.5-2.5 \mathrm{~mm}$. Specimens recovered from La Terma are left in open nomenclature since they are probably 7-8th instars because the length is less than $1 \mathrm{~mm}$, and the calcified inner lamella is very narrow.

Local distribution: immature valves of Herpetocypris sp. with soft parts not well preserved were recovered from sediments of the active channel (Later3).

Subfamily CYPRIDOPSINAE Bronshtein 1947

Genus Cypridopsis Brady 1868

Cypridopsis fuhrmanni (Mèhes 1914)

Plate 2, figure 9-11

Cypridopsis fuhrmanni MÈHES 1914, p. 646-648, figs. 3a-h, figs. 4a-e.

Material: the following material is deposited at the Laboratorio de Micropaleontología, Facultad de Ciencias Exactas y Naturales, Universidad de Buenos Aires; repository numbers are given in brackets: a) LV preserved on a cavity slide 
TABLE 2

Abundance of ostracods in La Terma hot spring, Catamarca, Southern Altiplano. Only living individuals (specimens containing soft part even when they were not well preserved) were considered. For microhabitat description, see Table 1.

\begin{tabular}{cccccccccc}
\hline \hline Sample & \multicolumn{1}{c}{$\begin{array}{c}\text { Darwinula } \\
\text { stevensoni }\end{array}$} & \multicolumn{2}{c}{$\begin{array}{c}\text { Penthesilenula } \\
\text { incae }\end{array}$} & \multicolumn{2}{c}{$\begin{array}{c}\text { Hemicypris } \\
\text { panningi }\end{array}$} & $\begin{array}{c}\text { Candona } \\
\text { sp. }\end{array}$ & $\begin{array}{c}\text { Cypridopsis } \\
\text { fuhrmanni }\end{array}$ & $\begin{array}{c}\text { Herpetocypris } \\
\text { sp. }\end{array}$ \\
adults & juvenils & adults & juvenils & adults & juvenils & adults & adults & juvenils \\
Later 2 & 19 & 66 & 0 & 0 & 62 & 7 & 1 & 0 & 0 \\
Later 3 & 4 & 12 & 0 & 0 & 15 & 1 & 0 & 2 & 0 \\
Terma 4/4 & 0 & 0 & 2 & 0 & 3 & 2 & 0 & 3 & 2 \\
& 0 & 18 & 4 & 40 & 3 & 0 & 0 & 0 \\
\hline
\end{tabular}

(FCEN-LM 2939); b) Cp preserved on a cavity slide (FCEN-LM 2940); c) RV preserved on a cavity slide (FCEN-LM 2941).

Description: Cp subtriangular, reniform no elongated in lateral view, greatest height of anterior margin situated almost exactly in the middle. Dorsal margin strongly arched, defining an obtuse angle whose apex coincides with the anterior cardinal angle. Posterior cardinal angle visible. Anterior margin evenly nearly rounded, the posterior one truncated, ventrally sub-rounded and dorsally straight. Ventral margin with an anterior smooth concavity, posterior moderately convex, anterior straight. External surface of the valves smooth, pitted in the anterior margin and extended to the postero-ventral margin. Few simple and spread normal pores. Few setae in the anterior margin. Adont hinge. LV with a smooth bar. Calcified inner lamella narrow but widest in the anterior margin. Anterior margin with well developed vestibule. Rcp short, straight and numerous. Cms forming not a very compact group with four big spots and two sherter ${ }_{\wedge}$ of antero-ventral position.

Measurements: length $901-920 \mu \mathrm{m}(\mathrm{n}=3)$; height $577-599 \mu \mathrm{m}$ $(\mathrm{n}=3)$.

Remarks: this is the first record of Cypridopsis fuhrmanni since its original description by Mèhes (1914). Cypridopsis fuhrmanni is quite similar to Cypridopsis sp. aff. $C$. huaronensis (Mourguiart written communication 1987) from Titicaca Lake, Bolivia, but the former is smaller (maximum length $0.42 \mathrm{~mm}$ to $0.36 \mathrm{~mm}$ ) and the posterior margin is lower.

Distribution: individuals with soft parts not well preserved were found in La Terma hot spring bottom sediments (Later3 and Later2). Cypridopsis fuhrmanni was originally described from Andean lakes from Colombia and Argentina between 1530 and 2640m asl (Mèhes 1914).

\section{DISCUSION}

Recent ostracods have been described from lakes, streams, ponds, groundwater environments, damp leaf litter, soils, marshes and hot springs. In the former, occurrence in waters with temperatures beyond $30^{\circ} \mathrm{C}$ has been reported from Africa (Moniez 1893), Europe (Gülen 1985; Ponyi 1992), and Asia (Menzel 1923). In America, hot springs from the United States contain a relatively well studied fauna (Wickstrom and Castenholz 1973, 1985; Petersen and Mott 2002; Külkoylouglu et al. 2003).

Two thermophilic species are found in the genus Heterocypris: H. balnearia (Moniez 1893) and H. sabirae Gülen 1985 both from spring waters with temperatures reaching $50^{\circ} \mathrm{C}-51.5^{\circ} \mathrm{C}$ (Moniez 1893, Klie 1939, Gülen 1985). Thermopsis thermo- phila Külk̈̈ylüelth Meisch and Rust were found at a maximum of $54^{\circ} \mathrm{C}$ (Külk̈̈ylïeðlth et al. 2003). Several other species such as Cypria ophtalmica (Jurine), Cypridopsis vidua (Müller), Plesiocypridopsis thermarum (Tagliasacchi-Masala), Darwinula stevensoni, Metacypris cordata (Brady and Robertson), Limnocythere sappaensis Staplin, Cyprinotus fuscus (Jurine) as well as other species with no taxonomic indications or not properly described belonging to "Darwinula", Physocypria, Chlamydotheca, Herpetocypris, Eucypris, Cyprinotus, Candona and Potamocypris (these later probably

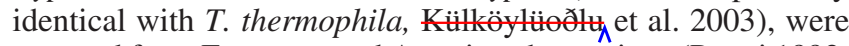
reported from European and American hot springs (Ponyi 1992, Brues 1932, Castenholz 1967, Wickstrom and Castenholz 1973, 1985, Furnish et al. 2002).

We consider La Terma hot spring as thermal waters because temperature is higher than the annual mean temperature of the region. Air mean temperature in the area ( 2 to 12 daily measures from $01 / 13 / 2004$ to $09 / 04 / 2004$ ) was $3.9^{\circ} \mathrm{C}$, while water temperature was $38^{\circ} \mathrm{C}$ in the discharge well, and $30^{\circ} \mathrm{C}$ to $28^{\circ} \mathrm{C}$ in the sampled sites. The water is of $\mathrm{Na}^{+}-\mathrm{Ca}^{++}-\mathrm{HCO}^{-}-\mathrm{Cl}^{-}$type with a total mineralization of $1349 \mathrm{~g} / \mathrm{l}$ and neutral $\mathrm{pH}$. The genesis of these thermal waters and their warming remain still not investigated, but active thermal springs in NW Argentina are related to volcanic activity (Kasemann et al. 2004).

Living ostracods of La Terma hot spring are actually taxonomically expected, represented by Darwinula stevensoni, Penthesilenula incae and Hemicypris panningi. The former is ubiquitous and represents the most abundant and widely distributed species, living in coarse-grained sediments and in relation with aquatic plants. Darwinula stevensoni lives attached on leaves of aquatic macrophytes and floats behind the surface layer. Penthesilenula incae is bottom-dweller, especially abundant in coarse-grained sediments with abundant organic matter.

In addition of species mentioned above, also individuals with soft parts not well preserved of Candona sp., Herpetocypris sp., and Cypridopsis fuhrmanni were found. Due to the features of the environment (the sampled site is just only 200m downstream of the well and there is no any other freshwater input) it is considered that these species are actually autochthones and the absence of living individuals is exclusively due to the deficiency of sampling.

All the nominated species from La Terma hot spring were previously described from non-thermal waters. They have regional or cosmopolitan distribution, and belong to genera with effective dispersal strategies and wide ecological tolerances. Species from La Terma hot spring should be considered eurythermic species well represented in warm water habitats, but no thermophilic species linked to 'high' temperatures. The cosmo- 
politan and ubiquitous Darwinula stevensoni has a worldwide distribution. Able to survive in a wide range of environmental conditions including hot springs, it has an unusual wide tolerance range for both salinity (0-30 gr/l) and temperature $\left(2{ }^{\circ} \mathrm{C}\right.$ to $30^{\circ} \mathrm{C}$ ) (Van Doninck et al. 2002). The presence of Darwinula stevensoni in these thermal waters is not surprising, but the discovery of $P$. incae, $H$. panningi, and $C$. fuhrmanni in La Terma hot spring improves the knowledge of their ecological requirements -especially ranges of thermal tolerance- since these species have been previously described only from Andean ponds and lakes without thermal influences. Rossetti et al. (1996) redescribed Penthesilenula incae from a "shallow pool and canal in largely dry Laguna, turbid, many algae, c. $10 \mathrm{~cm}$ deep, c. $150 \times 50 \mathrm{~m}$ large; water temperature $=15.2^{\circ} \mathrm{C}, \mathrm{pH}=9.3$, conductivity $=767 \mathrm{i} / \mathrm{Sm}$ " in Bolivia at $3810 \mathrm{~m}$ asl. Mourguiart et al. (1986, 1997), Mourguiart (1992) and Mourguiart and Montenegro (2002) mention P. incae (sometimes as Darwinula sp.) inhabiting nearshore environments in the Titicaca Lake and adjacent areas, associated with macrophytes and organic rich sediments, salinity range between 0.8 to $2 \mathrm{~g} / \mathrm{l}, 0-60 \mathrm{~m}$ deep. Ecological data have not been published for Hemicypris panningi neither Cypridopsis fuhrmanni.

In a regional context, this fauna represents an interesting finding because it is an assemblage of darwinulids and cypridoids facing extreme environmental factors (e.g., high UV radiation, sustained strong wind action), inhabiting a very isolated high-altitude warm-water environment. The surroundings provide several examples of high-Andean saltpans and saline wetlands locally called vegas. According to preliminary studies, nearest vegas are inhabited mainly by limnocytherids, whereas cypridoids dominates flowing waters such as rivers, streams and springs (Laprida et al., 2006). Although the taxonomic composition of the fauna from La Terma hot spring is predictable, the great abundance of individuals is surprising in comparison with other samples in the area, in which the fauna is relatively scarce and darwinulids are rare. We think that $\mathrm{La}$
Terma hot spring represents a more stable and predictable environment in comparison with the surroundings as consequence of the thermal origin of its waters, and this allows the development of rather big populations.

An interesting question is when and how these species could spread to populate this isolated setting. Several studies have documented strong environmental changes in the Altiplano during the last few millennia with large implication for temperature and water availability (Grosjean 2001; Grosjean et al. 2001; Bobst et al. 2003, Kull et al. 2003). In northern Chile and in the Bolivian Altiplano, paleoecological data show a remarkable change from cool and very arid conditions at the LGM (Late Glacial Maximum) to relatively humid conditions during LG (Late Glacial) and Early Holocene (Núñez et al. 2002, Argollo and Mourguiart 2000, Bobst et al. 2003; Grosjean et al. 2001). It is possible that much of the recent ostracods including those of La Terma could have reached southern Altiplano when new lakes, ponds, rivers and other aquatic habitats became available. Unfortunately, there are no detailed studies of ostracods in the Altiplano concerning the distribution in space and time to test this hypothesis. The continuous sedimentary record before 20000 year BP is documented only at a limited number of sites (Argollo and Mourguiart 2000), and the majority of previous studies on ostracods have no detailed systematic descriptions (i.e., Mourguiart et al 1986, Wirrmann et al. 1988, Mourguiart 1992, among others).

Since the majority of the species of La Terma have a distribution that includes areas outside of the Altiplano, a colonization starting from lower surrounding areas can be considered. Darwinula stevensoni is common, ubiquitous and cosmopolitan. In South America it has been described from lowlands from Argentina and Brazil (Martens and Behen 1994, Würdig and Pinto 1999, Laprida in press). Cypridopsis fuhrmanni was previously found in Andean lakes from Argentina and Colombia between 1530 and 2640m asl (Mèhes 1914) and Hemicypris

\section{PLATE 1}

1-6 Darwinula stevensoni (Brady and Robertson 1870).

1 left valve, lateral external view, length: $619 \mu \mathrm{m}$, height: 236 $\mu$ m, Sample Later1, FCEN-LM 2920;

2 left valve, lateral external view, length: $594 \mu \mathrm{m}$, height: $194 \mu \mathrm{m}$, Sample Later1, FCEN-LM 2921;

3 right valve, lateral external view, length: $647 \mu \mathrm{m}$, height: $262 \mu \mathrm{m}$, Sample Later2, FCEN-LM 2922;

4 carapace, dorsal view, length: $600 \mu \mathrm{m}$, width: $260 \mu \mathrm{m}$, Sample Later1, FCEN-LM 2923;

5 left valve, lateral internal view, length: $597 \mu \mathrm{m}$, height: $239 \mu \mathrm{m}$, Sample Later1, FCEN-LM 2924;

6 right valve, lateral internal view, length: $648 \mu \mathrm{m}$, height: $268 \mu \mathrm{m}$, Sample Later2, FCEN-LM 2925.
7-10 Penthesilenula incae (Delachaux 1928).

7 right valve, lateral external view, length: $673 \mu \mathrm{m}$, height: $323 \mu \mathrm{m}$, Sample Terma4/4, FCEN-LM 2926;

8 left valve, lateral external view, length: $651 \mu \mathrm{m}$, height: $298 \mu \mathrm{m}$, Sample Terma4/4, FCEN-LM 2927;

9 right valve, lateral internal view, length: $653 \mu \mathrm{m}$, height: $295 \mu \mathrm{m}$, Sample Terma4/4, FCEN-LM 2928;

10 left valve, lateral internal view, length: $668 \mu \mathrm{m}$, height: $287 \mu \mathrm{m}$, Sample Terma4/4, (FCEN-LM 2929).

11 Candona sp., right valve, lateral external view, length: $480 \mu \mathrm{m}$, height: $287 \mu \mathrm{m}$ Sample Later1, (FCEN-LM 2930). 


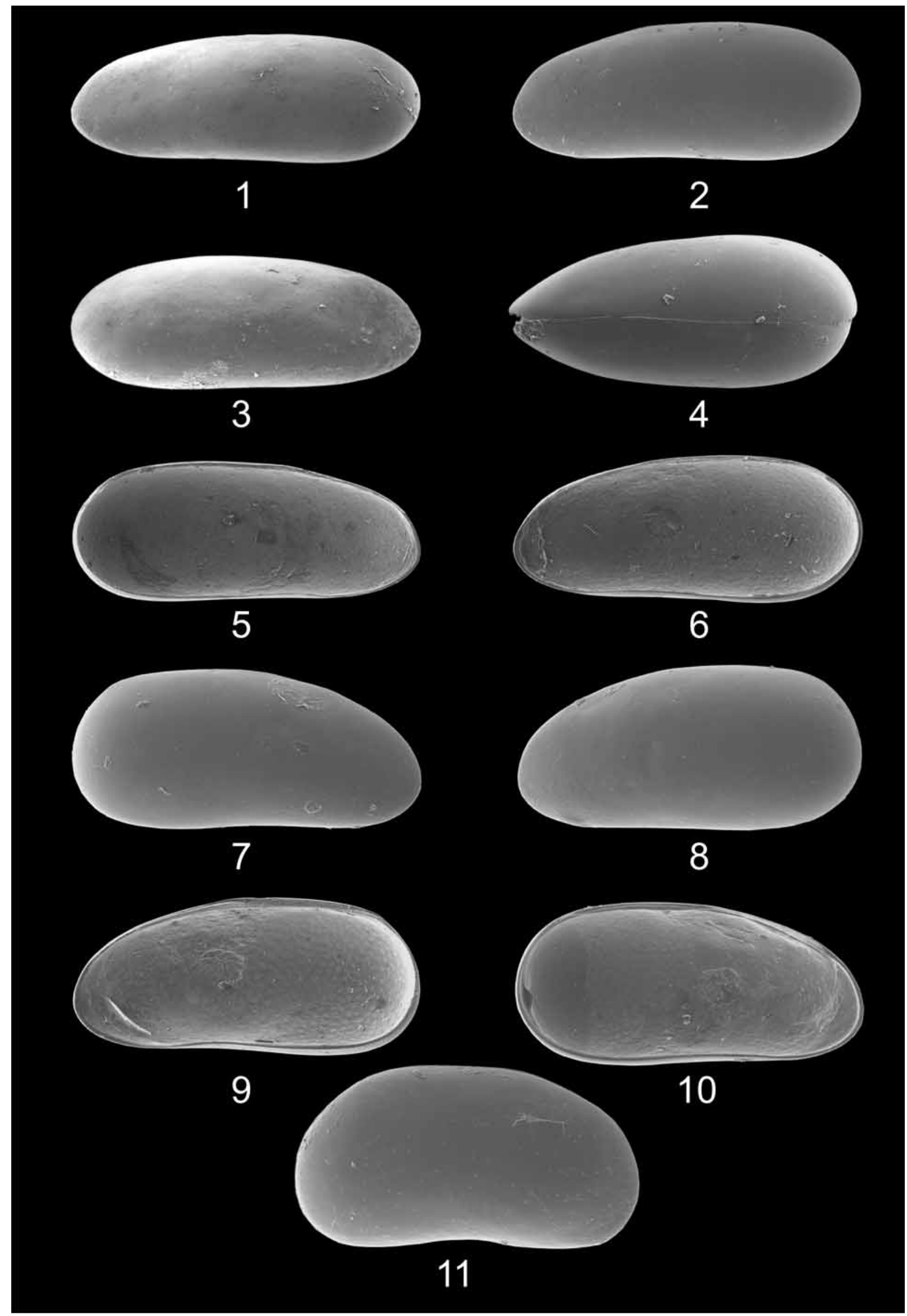


panningi was previously registered from central Chile (Valparajso) and Perú (Brehm 1934, Klie 1941, Hartmann 1962). Only $P$. incae is exclusively known from the Altiplano. The first record of this species is from about 20000 years BP (during LGM times) from the Titicaca lake (Mourguiart et al. 1997, 1998). Thereafter, during the LG and Holocene the record of $P$. incae is almost continuous in the Titicaca area (Rossetti et al. 1996; Mourguiart and Montenegro 2002). If the endemism of $P$. incae is confirmed, it will be necessary to analyze if, as other faunistic elements, endemic ostracods have resisted the drier periods (i.e. LGM, Mid-Holocene) surviving in high altitude ecological refuges. In a dry-environment scenario, lake levels were extremely low, most basins were completely dry, and the fauna ean only survive in areas with better local conditions, the so called "ecological refuges". During dry mid-Holocene, most faunal elements including mammals and their main predators (i.e., humans), concentrated their activities around the few remaining water bodies (Núñez and Grosjean 2003). This could have been either the LGM scenario, when only a few hardy species would have been able to survive remained in special places with large springs, regional river systems, and great lake basins -like the Titicaca basin- where resources remained stable through time and thresholds of water shortage were not surpassed. When more aquatic habitats were available again due to the more humid conditions, a rapid colonization of the dry Altiplano by species with effective dispersal strategies and wide ecological tolerances would have occurred. However, the only authoritative answer to this question would be documented in the sedimentary record, and this hypothetical scenario can be tested only by analyzing ostracod fossil assemblages from Late Quaternary sequences.

It is important to continue studying the distribution and ecology of recent ostracods of the Southern Altiplano in order to gener- ate a solid database to enhance paleoenvironmental studies in this region and to give information about the timing of appearance of recent ostracods in this amazing corner of the world.

\section{CONCLUSIONS}

This study represents a first attempt to describe ostracod species from the Southern Altiplano of Argentina. Six taxa inhabiting in an isolated hot spring at $4000 \mathrm{~m}$ asl were found. Darwinula stevensoni is ubiquitous and cosmopolitan: in South America it has been previously described from lowlands from Argentina and Brazil. Hemicypris panningi and Cypridopsis fuhrmanni were previously known from lower Andean areas situated to the north and to the south of the Altiplano. Only Penthesilenula incae is exclusively known from the Altiplano. Other two taxa, Candona sp. and Herpetocypris sp. are left in open nomenclature. Hemicypris panningi, Cypridopsis fuhrmanni, and Penthesilenula incae are found for the first time in thermal waters. Even when this fauna is taxonomically predictable in a hot spring, this is an interesting finding because it represents populations inhabiting an isolated high-altitude setting. The abundance of individuals in La Terma hot spring is surprising in comparison with other sampled sites in the area, in which total fauna is extremely scarce and darwinulids are rare. We think that La Terma represents a predictable environment in comparison with the surroundings as consequence of the thermal origin of its waters, and this allows the development of bigger populations.

\section{ACKNOWLEDGMENTS}

Financial support for this study was provided by Fundación Antorchas, Argentina (Project $N^{\circ}$ 14116-236). Partial support was provided by the Consejo Nacional de Investigaciones Científicas y Técnicas - CONICET (Argentina) (grant PT 17795574/04) Authors thanks to Dr Héctor Ostera (INGEIS)

\section{PLATE 2}

\section{1-7 Hemicypris panningi (Brehm 1934)}

1 female carapace, left lateral view, length: $589 \mu \mathrm{m}$, height: $362 \mu \mathrm{m}$, FCEN-LM 2931;

2 female carapace, dorsal view, length: $519 \mu \mathrm{m}$, width: $275 \mu \mathrm{m}$, FCEN-LM 2932;

3 female carapace, right lateral view, length: 596 $\mu \mathrm{m}$, height: $364 \mu \mathrm{m}$, FCEN-LM 2933;

4 female left valve, lateral internal view, length: $582 \mu \mathrm{m}$, height: $347 \mu \mathrm{m}$, FCEN-LM 2934;

5 male carapace, dorsal view, length: $586 \mu \mathrm{m}$, width: $288 \mu \mathrm{m}$, FCEN-LM 2935;

6 female right valve, lateral internal view, length: $625 \mu \mathrm{m}$, height: $385 \mu \mathrm{m}$, FCEN-LM 2936;
7 male left valve, length: $601 \mu \mathrm{m}$, height: $350 \mu \mathrm{m}$, FCEN-LM 2937.

8 Herpetocypris sp. Immature left valve, lateral external view, length: $876 \mu \mathrm{m}$, height: $400 \mu \mathrm{m}$, Sample Later3, FCEN-LM 2938 .

9-11 Cypridopsis fuhrmanni (Mèhes 1914).

9 left valve, lateral internal view, length: $871 \mu \mathrm{m}$, height: $572 \mu \mathrm{m}$, Sample Later3, FCEN-LM 2939;

10 carapace, dorsal view, length: $913 \mu \mathrm{m}$, width: $470 \mu \mathrm{m}$, Sample Later3, FCEN-LM 2940;

11 right valve, lateral external view, length: $887 \mu \mathrm{m}$,

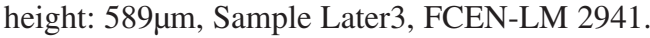



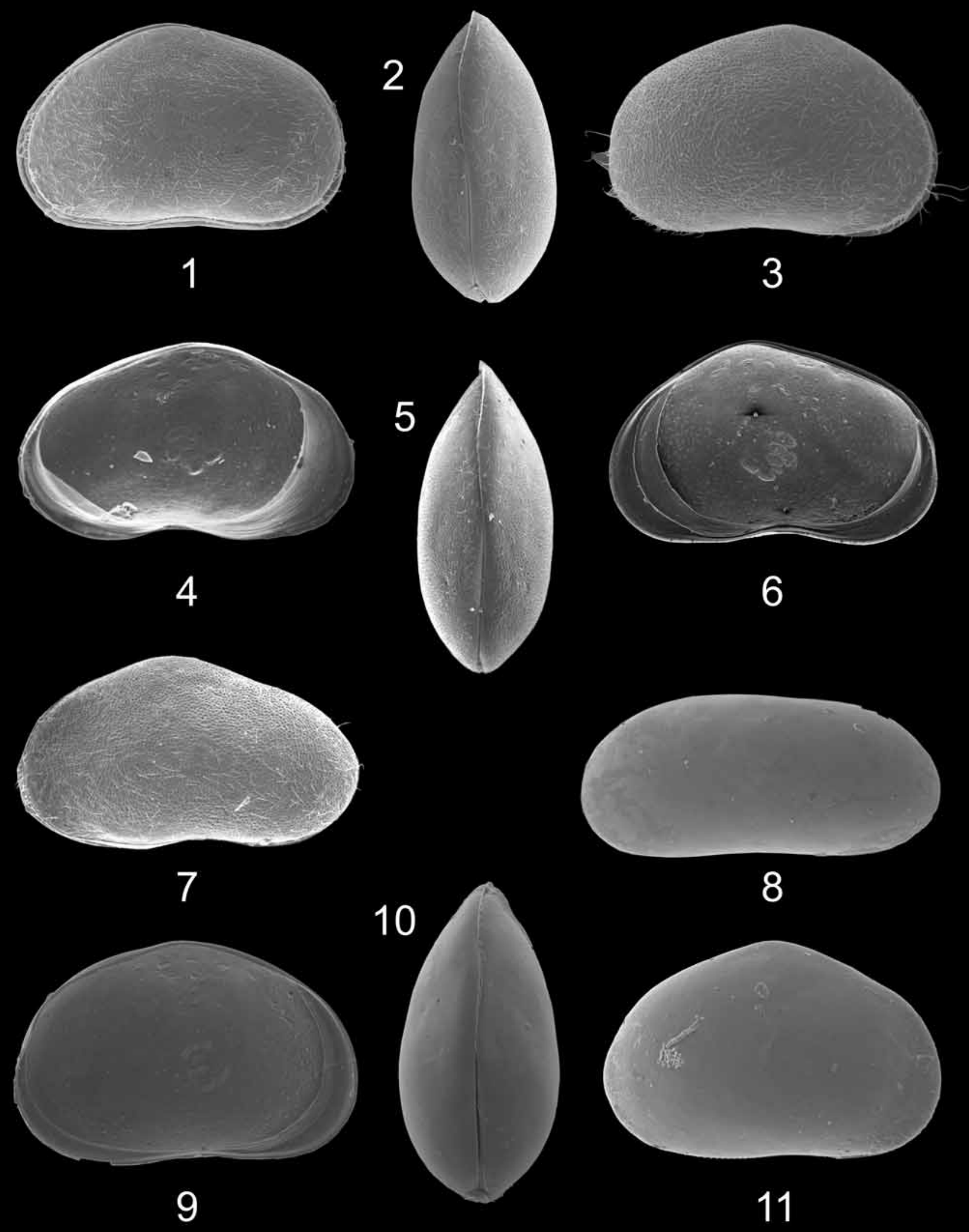

8

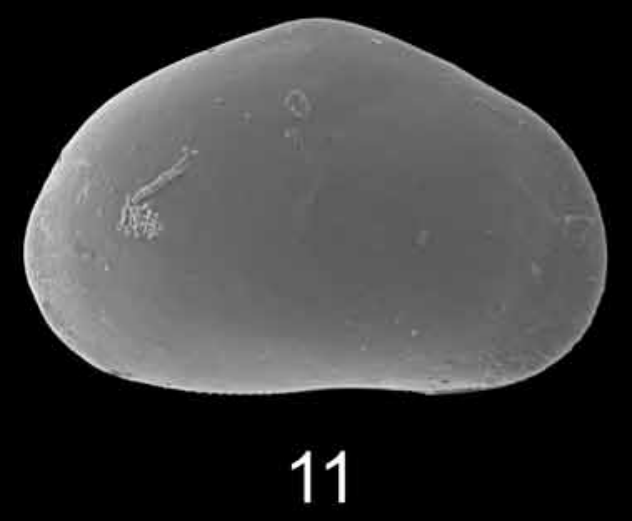


for water analysis, and Dr Estela Lopretto (Universidad Nacional de La Plata). A.D. profits a doctoral fellowship from CONICET.

\section{REFERENCES}

ARGERICH, F., 1976. Fisiografía de la provincia de Catamarca. Publicación de la Dirección Provincial de Cultura de Catamarca, 232 p.

ARGOLLO, J. and MOURGUIART, PH., 2000. Late Quaternary climate history of the Bolivian Altiplano. Quaternary International, 72: $37-51$

BAIRD, W., 1835. List of Entomostraca found in Berwickshire. Transactions of the Berkwickshire naturalist's club, 1: 95-100.

, 1845. Arrangement of the British Entomostraca, with a list of species, particularly noticing those which have as yet been discovered within the bounds of the Club. Transactions of the Berkwickshire Naturalist's Club, 2: 145-158.

BOBST, A.L., LOWENSTEIN, T.R., JORDAN, T.E. GODFREY, KU, T-L. and LUO, S., 2003. A 106 ka paleoclimate record from drill core of the Atacama desert, northern Chile. Palaeogeography, Palaeoclimatology, Palaeoecology, 173: 21-42.

BRADY, G. S., 1868. A monograph of the recent British Ostracoda. Transactions of the Linnean Society of London, 26: 353-495.

BRADY, G.S. and NORMAN, A.M., 1889. A monograph of marine and non-marine fresh-water Ostracoda of the North Atlantic and of Northwestern Europe. Section 1. Podocopa: Scientific Transactions of the Royal Dublin Society, series 2, 4: 63-270.

BRADY, G.S. and ROBERTSON, D., 1870. The Ostracoda and Foraminifera of Tidal Rivers. Annals and Magazine of Natural History, series 4, 6: 1-33, 307-309.

BREHM,V., 1934. Über Südamerikanische Ostrakoden des Zoologischen Staatinstitutes und Museums in Hamburg. Zoologischen Anzeiger, 108: 74-85.

BRUES,C. T., 1932. Further studies on the fauna of North American hot springs. Proceedings of the American Academy of Arts and Sciences, 67:186-303.

BUITRAGO, L. and LARRÁN, M., 1994. El clima de la Provincia de Jujuy. Facultad de Ciencias Agrarias. Universidad Nacional de Jujuy. Jujuy, 37 p.

CABRERA, A. L., 1976. Regiones fitogeográficas argentinas. In: Kugler, W. F., Ed., Enciclopedia Argentina de Agricultura y Jardinería. Fascículo 1. Buenos Aires, Editorial Acme, 58 p.

CABRERA, A. L. and WILLIINK, A., 1980. Biogeografía de América Latina. Secretaría General de la Asociación de Estados Americanos, Serie Biología, Monografía 13, Washington D.C., 120 p.

CASTENHOLZ, R. W., 1967. Environmental requirements of thermophilic blue-green algae. In: F. Bartsch, Ed., Environmental requirements of blue-green algae. Federal Water Pollution Control Administration, Corvallis, Oregon: 55-75.

COSTEllo, J. and AGUIRRE de COSTELlO, G., 1999. Manual de geografía de Catamarca. Editorial Sarquis. 183 p.

CUSMINSKY, G.C. and WHATLEY, R., 1996. Quaternary non-marine ostracodes from lake beds in northern Patagonia. Revista Española de Paleontología, 11: 143-154.
DADAY, E., 1902. Mikroskopische süsswaserthiere aus Patagonien, gesammelt von Dr. Filippo Silvestri. Természetrajzi futzetek, 25: 201-310.

DELACAHUX, T., 1928. Fauna invertébrée d'eau douce des hauts plateaux de Pérou. Bulletin de la Societé neuchateloise des sciences naturelles (nouvelle série), 1: 45-77.

FURNISH, J., MC IVER, J. and TEIGER, M., 2002. Algae and Invertebrate of a Great Basin Desert Hot Lake: a description of the Borax Lake ecosystem of Southeastern Oregon. Conference Proceeding. spring-fed wetlands: important scientific and cultural resources of the intermountain regions. http://www.wetlands.dri.edu, p.1-32.

GONZÁLEZ MOZO, M.E., MARTENS, K. and BALTANÁS, A., 1996. A taxonomic revision of European Herpetocypris Brady and Norman, 1889 (Crustacea, Ostracoda). Bulletin de l'institut Royal des Sciences Naturelles de Belgique, Biologie 66: 93-132.

GROSJEAN, M., 2001. Mid-Holocene climate in south-central Andes: humid or dry? Science, 292: 2391a.

GROSJEAN, M., VAN LEEUWEN, J.F.N., VAN DER KNAAP, W.O., GEYH, M.A., AMMANN, B., TANNER, W., MESSERLI, B., NUÑEZ, L. A., VALERO-GARCÉS, B. L. and VEIT, H., 2001. A $22000{ }^{14} \mathrm{C}$ year BP sediment and pollen record of climate change from Laguna Miscanti 23 $8^{\circ}$ 'S, northern Chile. Global and Planetary Change, 28: 35-51.

GÜLEN, D., 1985. The species and distribution of the group Podocopa (Ostracoda: Crustacea) in the freshwaters of western Anatolia. Istanbul Üniversitesi Fen Fakültesi Mecmuasi Seri B50: 65-80.

HARTMANN, G., 1962. Ostracoden des Eulitoralis. Teil III. Mitteilungen Hamburguischen Zoologisches Museum und Institut 1961 / 1962, 59/60:169-270

KASEMANN, S.A., MEIXNER, A., ERZINGER, J., VIRAMONTE, J.G., ALONSO, R. N. and FRANZ, G., 2004. Boron isotope composition of geothermal fluids and borate minerals from salar deposits (central Andes/NW Argentina). Journal of South American Earth Sciences, 16: 685-697.

KLIE, W., 1939. Zur Kenntnis von Cypris balnearia Moniez (Ostracoda). Zoologische Anzeiger, 126: 298-302.

1941. Süsswasserostracoden aus Perou. Beitrage Fauna Perous, (Hamburg)1:8192

KÜLKÖYLÜOGLU, O., MEISCH, C. and RUST, R.W., 2003. Thermopsis thermophila n. gen. n. sp. from hot springs in Nevada, U.S.A. (Crustacea, Ostracoda). Hydrobiologia, 499: 113-123

KULL, C., HANNI, F., GROSJEAN, M. and VEIT, H., 2003. Evidence of an LGM cooling in NW-Argentina $\left(22^{\circ} \mathrm{S}\right)$ derived from a glacier climate model. Quaternary International, 108: 3-11.

LAPRIDA, C., in press- Ostrácodos Recientes de la llanura pampeana, Buenos Aires, Argentina: ecología e implicancias paleolimnológicas. Ameghiniana $\boldsymbol{x}_{\mathrm{K}}$

LAPRIDA, C., MICHEL, J., and DÍAZ, A., 2006. Ecología de ostrácodos de Tinogasta Catamarca) como base para la reconstrucción de paleoambi $\bar{\equiv}$ holocenos del Noroeste argentino. Suplemento Ameghiniana,42: 34R.

MARTENS, K. and BEHEN, F., 1994. A checklist of the Recent nonmarine ostracods (Crustacea, Ostracoda) from the Inland waters of 
South America and adjacent islands, 1-84. Travaux Scientifiques du Musee National d'Historie Naturelle de Luxembourg, 22.

MARTENS, K and ROSSETTI, G., 2002. On the Darwinulidae (Crustacea, Ostracoda) from Oceania with the description of Vestalenula matildae. n. sp. Invertebrate Systematics, 16: 195-208.

MARTENS, K., WÜRDIG, N. and BEHEN, F., 1998. Maxillopoda. Non-marine Ostracoda. In: P.S. Young, Ed., Catalogue of Crustacea of Brazil. Rio de Janeiro. Museu Nacional. Série Livros 6: 45-65.

MÈHES, G., 1914. Süsswasser-ostracoden aus Columbien und Argentinien. Mémoires de la Societé neuchateloise des Sciences Naturelles, 5: 639-663.

MENZEL, R., 1923. Beitrage zur kenntaia der Mikrofauna von Niederiandisch - Ostidien v. Moosbewohnende Ostracoden aus dem Urwald von Tjibodas. Treubia, (3) 2: 193-196

MONIEZ, R., 1889. Sur quelques cladocères et un ostracode nouveau du lac Titicaca. Revue Biologique du Nord de la France, 11:419-429.

1893. Description d'une nouvelle espèce de Cypris vivant dans les eaux thermales du Hammam-Meskhoutine. Bulletin de la Societé zoologique française, 18: 140-142.

MOURGUIART, PH., 1992. The Ostracoda. In: Dejoux, C. and Iltis, A., Eds., Lake Titicaca: a synthesis of limnological knowledge. Kluwer Academic Publisher, 337-345.

,2000. Historical changes in the environment changes in Lake Titicaca: evidences from ostracod ecology and evolution. Advances in Ecological Research, 31: 497-520.

MOURGUIART, PH. and CORRÉGE, T., 1998. Ecologie et paléoécologie des ostracods actuelles et Holocenes de l'Altiplano bolivien. In: Crasquin-Soleau, S., Braccini, E. and Lethiers, F., Eds., What about Ostracoda! 103-115. Elf ep- Editions, Mémoires, 20.

MOURGUIART, PH. and MONTENEGRO, M. E., 2002. Climatic changes in the Lake Titicaca area: evidence from ostracod ecology. In: J. A. Holmes and A. R. Chivas, Eds., The Ostracoda. Applications in Quaternary Research. Geophysical Monograph Series 131: 151-166.

MOURGUIART, PH., WIRRMANN, D., FOURNIER, M. and SERVANT, M., 1992. Reconstruction quantitative des niveaux du petit lac Titicaca au cours de l'Holocene. Comptes Rendus de l'Academie des Sciences de Paris, 315: 875-880.

MOURGUIART, P., CARBONEL, J., PEUYPOUQUET, P., WIRRMANN, D. and VARGAS, C., 1986. Late Quaternary palaeohidrology of Lake Huinaymarca (Bolivia). Hidrobiologia, 143: 191-197.

MOURGUiART, P., ARGOLLO, J., CORRÈGE, T., MARTIN, L., MONTENEGRO, M.E., SIFEDDINE, A. and WIRRMANN, D., 1997. Changements limnologiques et climatologiques dans le basin du lac Titicaca, Bolivia, depuis 30000 ans. Compte Rendus de l'Academie des Sciences de Paris, 325: 139-146.

MOURGUIART, PH., CORRÉGE, T., WIRMANN, D., ARGOLLO, J., MONTENEGRO, M.E., POURCHET, M. and CARBONEL, P., 1998. Holocene palaeohydrology of Lake Titicaca estimated from an ostracod-based transfer function. Palaeogeography, Palaeoclimatology, Palaeoecology, 143: 51-72.
NÚÑEZ, L. and GROSJEAN, M., 2003. Biodiversity and human impact during the last 11,000 years in North-Central Chile. In: Bradshaw, G.A. and Marquet, P.A., Eds., Ecological studies, 162: 7-16

NÚÑEZ, L., GROSJEAN, M. and CARTAJENA, I., 2002. Human occupation and climate change in the Altiplano de Atacama, Chile. Science, 298: 821-824.

PETERSEN, J. C. and MOTT, D. N., 2002. Hot Spring National Park, Arkansas. Water Resources. Scoping Report. Technical Report NPS/NRWRD/NRTR - 2002/301. United States Department of the Interior. National Park Services, p. 1-32.

PINTO, I. D. and KOTZIAN, S.C.B., 1961. Novos ostracodes da Familia Darwinulidae e a variaçao das impressoes musculares. Boletim Instituto de Ciencias Naturais, 6: 31p.

PONYI, J. E. 1992. Studies of the Crustacea fauna of a Hungarian hot spring (Hviz Spa). Zoologischen Jahrbüchern abhteilung für Systematik Ökologie und Geographie, 119: 397-404.

PURPER, I. and WÜRDIG-MACIEL, N. L., 1974. Occurrence of Heterocypris incongruens (Ramdohr), 1808 - Ostracoda - in Rio Grande do Sul. Discussion on the allied genera: Cyprinotus, Hemicypris, Homocypris and Eucypris. Pesquisas, 3: 69-91.

RATTO, N., 2000. La estructura del registro arqueológico en la cuenca superior del Valle de Chaschuil (Dpto. Tinogasta, Catamarca). Arqueología, 10: 39-78.

ROSSETTI, G. and MARTENS, K., 1996. Redescription and morphological variability of Darwinula stevensoni (Brady and Robertson, 1870) (Crustacea, Ostracoda). Bulletin de L'institut Royal Des Sciences Naturelles de Belgique, Biologie, 66: 73-92.

1998. Taxonomic revision of the Recent and Holocene representatives of the Family Darwinulidae (Crustacea, Ostracoda), with a description of three new genera. Biologie, 68: 55-110.

ROSSETTI, G. HORNE, D. and MARTENS, K., 1998. On Darwinula stevensoni (BRADY and ROBERTSON). Stereo-Atlas of ostracod Shells, 25 (4) 17-22.

ROSSETTI, G., MARTENS, K. and MOURGUIART, P., 1996. On Darwinula incae Delachaux. Stereo Atlas of Ostracod Shells, 23 (9): 35-40.

SCHWALB, A., BURNS, S. J. and KELTS, K., 1999. Holocene environments from stable isotope stratigraphy of ostracods and authigenic carbonate in Chilean Altiplano Lakes. Palaeogeography, Palaeoclimatology, Palaeoecology, 148: 153-168.

SCHWALB, A., BURNS, S. J., CUSMINSKY, G., KELTS, K. and MARGRAFF, V., 2002. Assemblage diversity and isotopic signals of modern ostracodes and host waters from Patagonia, Argentina. Palaeogeography, Palaeoclimatology, Palaeoecology, 187: 323-339.

VALERO-GARCÉS, B., DELGADO-HUERTAS, A., RATTO, N., NAVAS, A. and EDWARDS, L., 2000. Paleohydrology of Andean Saline Lakes from Sedimentological and Isotopic Records, Northwestern Argentina. Journal of Paleolimnology, 24: 343-359.

VALERO-GARCÉS, B., DELGADO-HUERTAS, A., NAVAS, A., EDWARDS, L., SCHWALB, A., and RATTO, N., 2003. Patterns of regional hydrological variability in central-southern Altiplano $\left(18^{\circ}-26^{\circ} \mathrm{S}\right)$ lakes during the last 500 years. Palaeogeography, Palaeoclimatology, Palaeoecology, 30:1-20. 
VAN DONINCK, K., SCHÖN, I., DE BRUYN, L. and MARTENS, K., 2002. A general purpose genotype in an ancient asexual. Oecologia, 132: $205-212$.

WHATLEY, R.C. and CUSMINSKY, G. C., 1995. Quaternary lacustrine Ostracoda from northern Patagonia, Argentina. In: J. Riha Ed., Ostracoda and Biostratigraphy, 303-310, Rotterdam: A. A. Balkema.

, 1999. Lacustrine Ostracoda and Quaternary palaeoenvironments from the Lake Cari-Laufquen region, Río Negro Province, Argentina. Palaeogeography, Palaeoclimatology, Palaeoecology, 151: 229-239.

WHATLEY, R.C. and CUSMINSKY, G. C., 2000. Quaternary lacustrine Ostracoda from northern Patagonia, Argentina: a review. In: Gierlowski, E.H. and Kelts, K., Eds., Lake basins through space and time, 581-590. American Association of Petroleum Geologist, Studies in Geology, 46.
WICKSTROM, R. C. and CASTENHOLZ, R. W., 1973. Thermophilic Ostracod:aquatic Metazoan with the highest known temperature tolerance. Science 181: 1063-1064.

, 1985. Dynamics of Cyanobacterial and Ostracod interactions in an Oregon hot spring. Ecology 66: 1024-1041.

WIRRMANN, D., MOURGUIART, P., DE OLIVEIRA ALMEIDA, L. F., 1988. Holocene sedimentology and ostracods distribution in Lake Titicaca. Paleohydrological interpretations. Quaternary of South America and Antarctic Peninsula, 6:129-146

WÜRDIG, N. and PINTO, I.D. 1999. Classe Ostracoda. In: Buckup, L. and G. Bond-Buckup, Os crustáceos do Rio Grande do Sul, 116-143. Porto Alegre. E. Universidade/UFRGS.

Manuscript received July 12, 2005

Manuscript accepted March 13, 2006 